\title{
Redescription of Panaqolus purusiensis (LaMonte, 1935) (Siluriformes: Loricariidae) with identification key to the species of the genus
}

\author{
Christian Andreas Cramer
}

Despite Panaqolus purusiensis being described nearly 80 years ago, very little is known about it. The taxon was described based on a single specimen. Researching collection catalogues has revealed two more specimens that were caught together along with the holotype but had subsequently been deposited in different museums. Recent collections, including one from the type locality, have made more specimens available. Examination of this new material reveals that this species has three distinct color patterns that are size dependent. Specimens with standard length (SL) less than $30 \mathrm{~mm}$ show a coloration common among various species of Panaqolus consisting of regular bands on the body, fins and head. Specimens from 30-90 mm SL have a specific color pattern with thinner bands and those larger than $90 \mathrm{~mm}$ SL have a uniformly dark body with only the fins continuing to show bands. The most similar species are P. changae, $P$. gnomus, $P$. maccus, and $P$. nocturnus. The first three can easily be distinguished by their coloration and by body proportions. Specimens of $P$. nocturnus of more than $90 \mathrm{~mm}$ SL however are nearly indistinguishable from P. purusiensis of the same size, making identification difficult.

Apesar de Panaqolus purusiensis ter sido descrita há quase 80 anos, sabe-se muito pouco sobre ela. $\mathrm{O}$ táxon foi descrito com base em um único exemplar. No entanto, pesquisas em catálogos de coleções ictiológicas revelaram mais dois exemplares que foram capturados junto com o holótipo, porém depositados em outros museus. Coletas recentes, incluindo a localidade-tipo, disponibilizaram mais espécimes. O exame deste material revelou que a espécie tem três padrões distintos de coloração dependendo do tamanho. Indivíduos com até $30 \mathrm{~mm}$ de comprimento padrão [CP] apresentam bandas regulares no corpo, nas nadadeiras e na cabeça, padrão de colorido comum em várias espécies de Panaqolus; indivíduos de 30-90 mm CP apresentam um padrão específico de coloração, com bandas claras mais finas; e acima de $90 \mathrm{~mm}$ CP o corpo é uniformemente escuro e somente as nadadeiras continuam expondo bandas. As espécies mais parecidas com $P$. purusiensis são $P$. changae, $P$. gnomus, $P$. maccus e $P$. nocturnus. As três primeiras podem facilmente ser distinguidas pelo padrão de coloração e pelas proporções do corpo, porém, exemplares de $P$. nocturnus com mais que $90 \mathrm{~mm}$ CP são muito parecidos com P. purusiensis do mesmo tamanho, dificultando a identificação.

Key words: Catfish, Neotropical, Panaque, Rio Purus, Taxonomy.

\section{Introduction}

Schaefer \& Stewart (1993) published a revision of the small Panaque and defined a Panaque dentex species group. In 2001, Isbrücker \& Schraml described the new genus Panaqolus for this group, with P. gnomus as type species. Initially this new genus was treated as a synonym of Panaque (Chockley $\&$ Armbruster, 2002; Fisch-Muller, 2003) or as a subgenus (Armbruster, 2004, 2008; Lujan et al., 2010). But later in their checklists, Ferraris (2007) and Eschmeyer (2012) considered Panaqolus as a valid taxon. Based on molecular data, Cramer et al. (2011) found Panaqolus to be clearly distinct from Panaque, but included only a few representatives of Hypostominae as the focus of the study was on two other loricariid subfamilies. Recently, Fisch-Muller et al. (2012) described a new species of Panaqolus, thus again recognizing the genus.

Molecular data show Panaqolus to be a distinct genus, with Peckoltia, Hypancistrus, and Scobinancistrus being the most

Universidade Federal de Rondônia - Laboratório de Ictiologia e Pesca - Departamento de Biologia - BR-364, Km 9.5, 76801-059 Porto Velho, Rondônia, Brazil.Cramerc@gmx.de 
closely related taxa (Cramer et al., 2011). Fisch-Muller et al. (2012) found Panaqolus and Peckoltia to be closely related analyzing cytochrome $c$ oxidase I (COI) sequences from Hemiancistrus, Panaqolus, Peckoltia, and Pseudacanthicus. Panaqolus lacks a posterior orbital notch and a ventrolateral keel on the caudal peduncle (characters present in Panaque). Furthermore, Panaqolus remain smaller $(<15 \mathrm{~cm} \mathrm{SL} v s .>27.8$ $\mathrm{cm}$ with some species of Panaque reaching more than $60 \mathrm{~cm}$ SL). Panaqolus and Panaque both possess acutely angled rows of robust spoon-shaped teeth as a common character that is additionally shared with the Hypostomus-cochliodongroup. The genus Panaqolus is accepted and used for the species redescribed herein, however, a phylogenetic study is in preparation to analyze these relationships in more detail.

At the moment, the genus Panaqolus comprises the following described species: P. dentex (Günther, 1868), P. purusiensis (LaMonte, 1935), P. albomaculatus (Kanazawa, 1958), $P$. changae (Chockley \& Armbruster, 2002), P. gnomus (Schaefer \& Stewart, 1993), P. maccus (Schaefer \& Stewart, 1993), $P$. nocturnus (Schaefer \& Stewart, 1993), and $P$. koko Fisch-Muller \& Covain, 2012, although there are doubts about the correct generic assignment of $P$. koko as its body shape and its teeth differ from typical Panaqolus (Fisch-Muller et al., 2012). Together with recorded but undescribed species, they are distributed across Brazil, Ecuador, French Guiana (only P. koko), Guyana (Miller, 2002), Colombia (Braitmayer, 2010), Peru, and Venezuela.

The description of Panaqolus purusiensis was based on a single specimen collected by B. A. Krukoff in 1934. Apparently, LaMonte did not know that two more specimens had been collected together with the holotype, but had been deposited in different collections (Conci \& Michelangeli, 1974; Schaefer \& Stewart, 1993). Only one of these additional specimens (USNM 94665) had been examined by Schaefer \& Stewart (1993) in their revision. LaMonte also had not been aware that there had already been an available description of another small species of Panaque (P. dentex Günther, 1868). She, at least, does not refer to this species and her characters only distinguish P. purusiensis from large Panaque. As the species description is rather brief and does not provide many useful characters, a redescription is provided here. This is based on all three specimens collected by B. A. Krukoff, additional specimens recently collected at the type locality, two specimens from Acre State, Brazil, and three from the Purus drainage in Peru.

\section{Material and Methods}

Counts, measurements and terminology follow Lujan et al. (2010). All measurements were made to the nearest 0.1 $\mathrm{mm}$ with the use of digital or analog calipers. The following abbreviations were used: SL, standard length; HL, head length; and DW, oral disk width. Institutional abbreviations are as listed in Ferraris (2007) with the addition of UFRO-I for Ichthyological Collection of Universidade Federal de Rondônia, Brazil.

\section{Panaqolus purusiensis (LaMonte, 1935) Figs. 1a, 2-4}

Diagnosis. The presence of dark bars on the trunk (in specimens smaller than $85 \mathrm{~mm} \mathrm{SL}$ ) and bands on the fins alternating with light interspaces distinguishes Panaqolus purusiensis from all congeners except $P$. changae, P. maccus, and $P$. gnomus. Panaqolus purusiensis can be distinguished from $P$. changae by the dorsal-adipose distance (16-25\% of SL vs. $14-17 \%$ of SL $[\mathrm{n}=8]$ ), by the coloration of its head (straight light lines vs. worm lines) and the dark bars on body and fins (dark bars wider than light interspaces $v s$. dark bars as wide as or thinner than the lighter interspaces) and the larger adult size (130 mm SL vs. $86 \mathrm{~mm} \mathrm{SL})$. Panaqolus purusiensis differs from $P$. gnomus by the posterodorsal to anteroventral orientation of bars on the trunk ( $v s$. anterodorsal to posteroventral $[\mathrm{n}=30])$ and the larger adult size $(130 \mathrm{~mm}$ SL vs. $70.8 \mathrm{~mm} \mathrm{SL}$ ). From P. maccus it can be separated by a shorter head length (33-39\% SL vs. 37-42\% [n = 8]), the smaller cleithral width (31-36\% SL vs. 34-44\%), the greater dorsal-pelvic depth (22-32\% SL vs. 19-23\%), and the larger adult size (130 mm SL vs. $87.6 \mathrm{~mm} \mathrm{SL}$ ).

Panaqolus purusiensis can be distinguished from $P$. albomaculatus by its body and fin coloration (alternating dark and light bars or uniformly brown body [in large specimens] $v s$. small, white or yellowish spots on body and fins $[\mathrm{n}=$ 26]), by the position of the dentaries (touching in the middle forming a $\mathrm{V}$ with approximately $70^{\circ}$ angle $v$ s. normally not touching, forming a very acute angle or being nearly parallel [Fig. 1]), by the mouth width (42-50\% HL vs. 32-44\%) and the longer maxillary barbel length (10-18\% HL vs. 2-10\%). As $P$. dentex do not pass a size of $74 \mathrm{~mm} \mathrm{SL}$, a size where $P$. purusiensis still shows its banded pattern on body and fins, these two species can easily be separated as the former species never shows bands on body or fins $(n=20)$.

The lines on the head and trunk may be faded in large specimens ( $>85 \mathrm{~mm} \mathrm{SL}$ ) of $P$. purusiensis. In this case, these specimens are especially difficult to distinguish from large $P$. nocturnus (Fig. 5). Panaqolus purusiensis usually has a higher caudal peduncle than $P$. nocturnus $(11-14 \%$ SL vs. $10-12 \%$ $[\mathrm{n}=30])$, large individuals $(>85 \mathrm{~mm} \mathrm{SL})$ have a lower thorax length to pelvic-dorsal depth ratio (86-98\% SL [mean 93\%] vs. $86-125 \%$ SL [mean 103\%), and a lower dorsal-pectoral depth to dorsal-pelvic depth ratio (107-116\% SL [mean 111\%] vs. $110-142 \%$ SL [mean 122\%]). Panaqolus koko $(\mathrm{n}=1)$ has uniformly dark body and fins ( $v s$. banded) and nearly quadrate teeth with strong lateral cusps (vs. round teeth without or with small lateral cusps). 


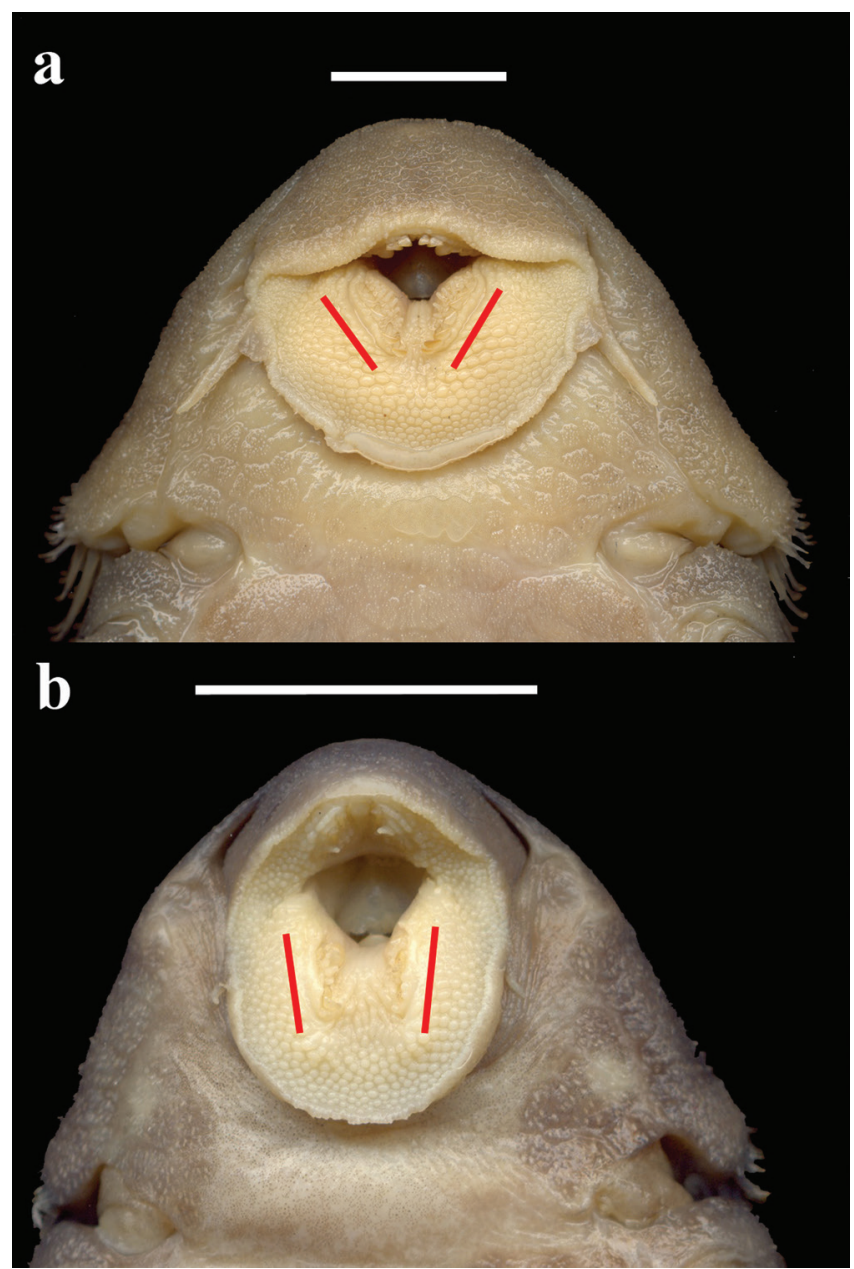

Fig. 1. Mouth of a) Panaqolus purusiensis (MUSM 39425) and b) P. albomaculatus (UFRO-I 17825) with the different angles of the dentaries.

Description. Counts and proportional measurements in Table 1. Medium-sized loricariid with standard length of measured specimens up to $130.4 \mathrm{~mm} \mathrm{SL}$. Dorsal profile of head and snout strongly convex from snout tip to posterior tip of supraoccipital, straight and posteroventrally slanted between dorsal-fin origin and adipose-fin origin, gently concave through caudal peduncle to posterior tip of last procurrent caudal fin ray. Dorsal orbit margin slightly raised, forming a gentle ridge, narrowing anteriorly, from anterior orbit margin to area lateral to nares. Dorsal surface of trunk transversely flattened from dorsal-fin origin to adipose-fin base. Ventral profile of head and body flat from oral disk to anal-fin origin. Caudal peduncle oval in cross-section and relatively deep (11-14\% SL).

Greatest body depth at dorsal-fin origin. Pectoral-fin origin just posterior to orbit; pelvic-fin origin at vertical through origin of second dorsal-fin ray; anal-fin origin shortly posterior after vertical through origin of last dorsal- fin ray. Adipose fin with well-ossified leading spine bearing odontodes.

Dorsal fin II, 7-8 (holotype II, 8), pectoral fin I,6, pelvic fin i,5, anal fin i,4, caudal fin i,13-14,i (holotype i,13,i). Spinelet V-shaped, dorsal-fin spine lock functional, posterior fin margin straight, margin of last two rays rounded. Dorsal-fin origin closer to vertical line passing through pelvic-fin origin than to vertical line passing through pectoral fin origin; not reaching adipose fin when adpressed. Adipose fin triangular; adipose-fin spine slanted posteroventrally, tip straight to curved ventrally, pointed; posterior margin of adipose-fin membrane concave to nearly vertical. Pectoral-fin spine robust, membrane of interspace between spine and first ray may bare fleshy extension in large individuals, posterior fin margin straight, when depressed reaching $1 / 3$ of pelvic fin. Pelvic-fin spine robust, posterior margin slightly rounded, when adpressed reaching mid-length of anal fin. Caudal fin forked.

Head and body entirely plated except for small naked area around dorsal-fin base, snout without naked area near tip. Abdomen of adults ranging from incompletely plated (plates only in skin ventral to pectoral girdle, along sides, and in skin posterior to pelvic fin) to completely covered by small irregularly arranged platelets (specimens $>85 \mathrm{~mm} \mathrm{SL}$ ). Abdomen of juveniles unplated. Area dorsal to pelvic-fin base below ventral margin of inframedian plate row usually with 1-3 small plates, without smaller platelets and with large intervening naked space. Supraoccipital bordered posteriorly by 2-3 (mode 2) scutes on each side. Body with pronounced lateral ridge extending from cleithrum to posterior margin of fifth or sixth plate of the inframedian plate row; ridge gradually decreasing in prominence posteriorly. Trunk without elevated ridges.

Head and body covered by odontodes of uniform size and distribution. Enlarged odontodes on anterodorsal border of pectoral-fin spine. Cheek odontodes hypertrophied with tips recurved laterally, longest odontode extending to posterior cleithrum margin. Interorbital space straight or slightly convex. Eye moderately large, dorsolaterally placed; orbit diameter $14-22 \%$ HL. Iris diverticulum present. Nares small and ovoid, slightly longer than wide.

Oral disk round, distal margin of upper lip well separated from maxillary barbel base. Maxillary barbels of moderate length (10-18\% HL). Lips moderately rugose, small patch of elongate fleshy papillae medial to each tooth row. Border of lips smooth.

Teeth spoon-shaped and normally unicuspid; sometimes a very small lateral cusp is present that may be reduced to a lateral dent (Fig. 6). Premaxillary teeth 5-7 per ramus (mode 5), mandibular teeth 4-7 per ramus (mode 6). Premaxillae angled at approximately $90^{\circ}$, dentaries at approximately $70^{\circ}$ (Fig. 1). 


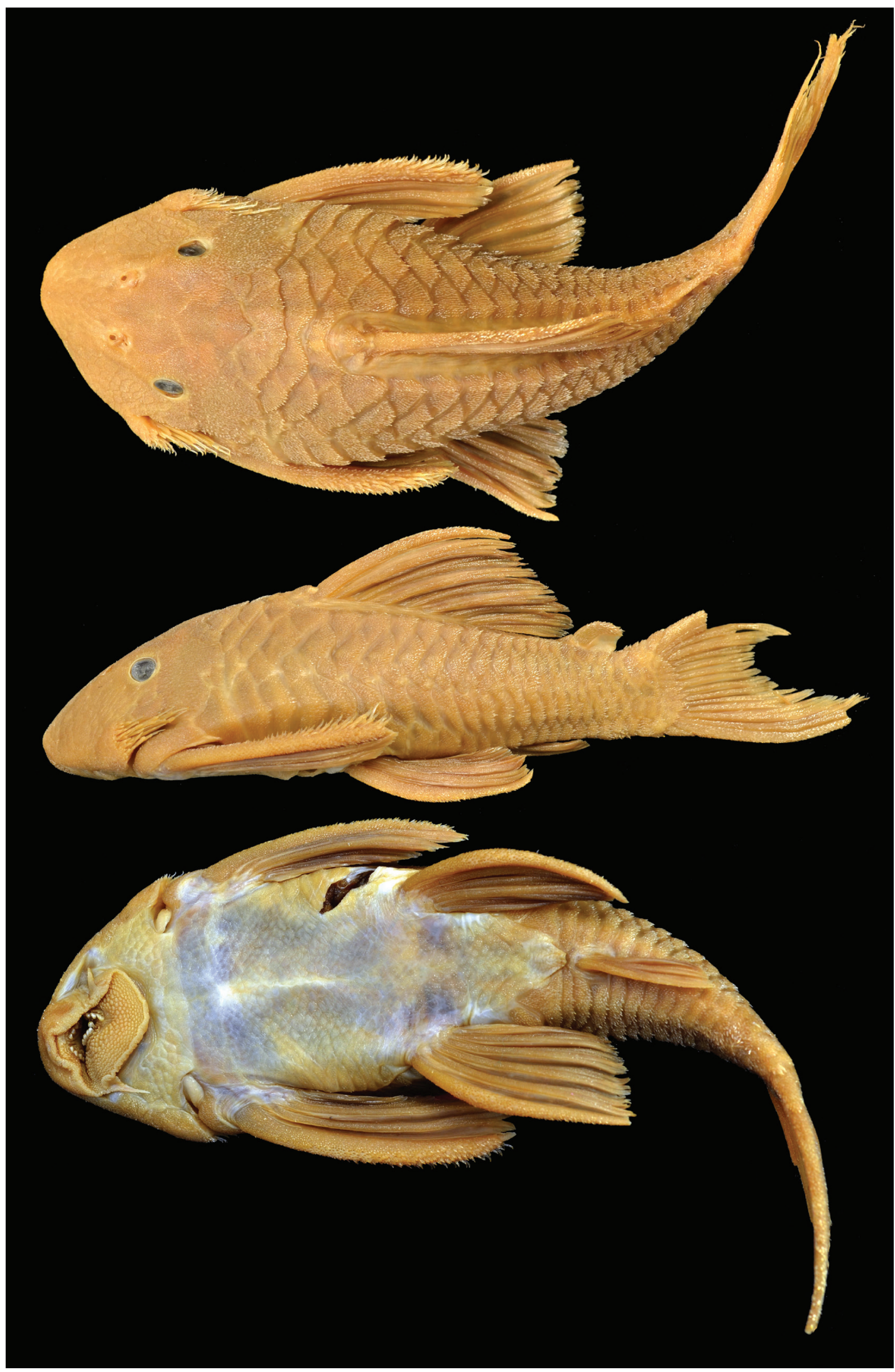

Fig. 2. Dorsal, lateral, and ventral views of Panaqolus purusiensis, holotype, AMNH 12600, $106.7 \mathrm{~mm}$ SL, Brazil, Acre, Purus drainage, vicinity of the mouth of rio Macauã, a tributary of rio Iaco. 


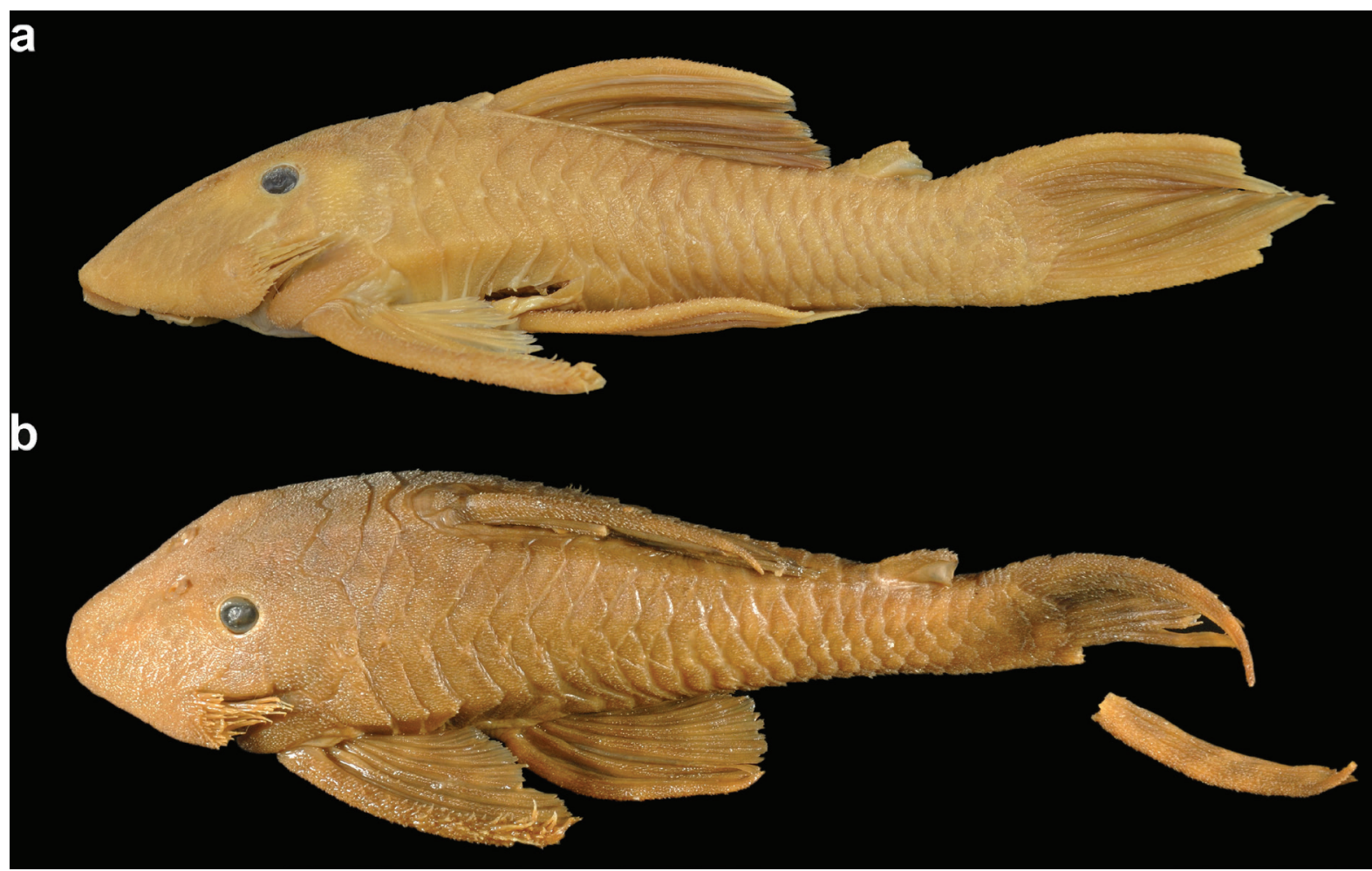

Fig. 3. Lateral views of the topotypes of Panaqolus purusiensis collected by Krukoff: a) USNM 94665, $110.6 \mathrm{~mm}$ SL; b) MSNM Pi43, 126.4 mm SL. Photo by G. Bardelli.

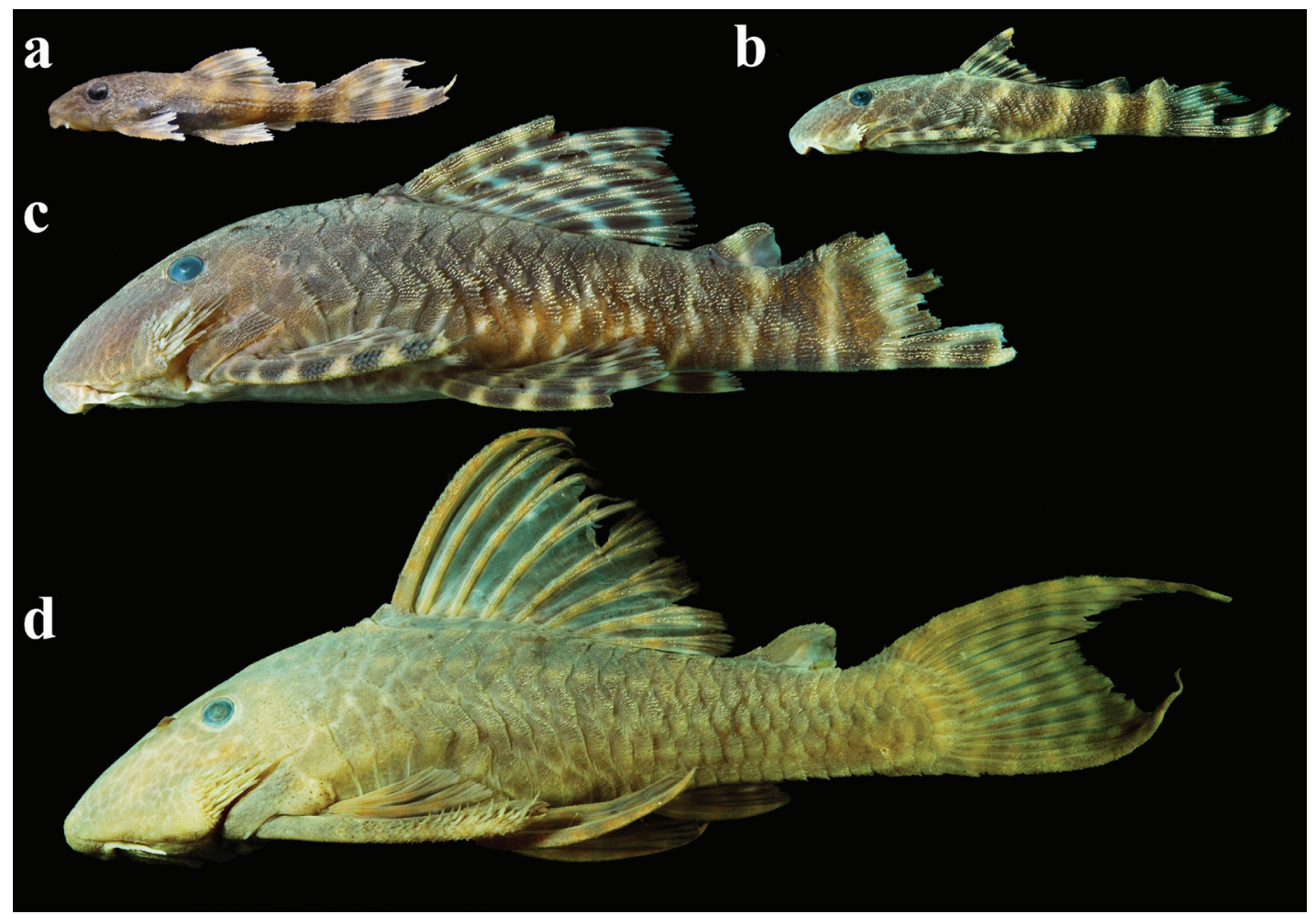

Fig. 4. Lateral views of recently collected Panaqolus purusiensis to show the different size-dependent color patterns: a) 15.5 mm SL; b) 42.8 mm SL; c) 83.3 mm SL (all UFRO-I 17720); d) 130.4 mm SL (MUSM 39425). Photos by B. S. F. Barros. 
Table 1. Selected morphometric features of Panaqolus purusiensis and P. nocturnus. Values are given as percent of standard length or head length. $\mathrm{SD}=$ standard deviation, $\mathrm{n}=$ number of specimens, $\mathrm{H}=$ holotype. Interlandmarks (ILM) are the two points between which measurements were taken (from Lujan et al., 2010).

\begin{tabular}{|c|c|c|c|c|c|c|c|c|c|}
\hline \multirow[b]{2}{*}{ ILM } & \multirow[b]{2}{*}{ Measurement } & \multicolumn{4}{|c|}{ P. purusiensis } & \multicolumn{4}{|c|}{ P. nocturnus } \\
\hline & & $\mathrm{H}$ & $\mathrm{n}$ & range & mean \pm SD & $\mathrm{H}$ & $\mathrm{n}$ & range & mean \pm SD \\
\hline \multicolumn{10}{|c|}{ Percent of Standard Length } \\
\hline $1-10$ & Predorsal length & 49.9 & 13 & $42.1-47.9$ & $44.7 \pm 1.9$ & 56.4 & 30 & $40.3-47.3$ & $42.7 \pm 1.9$ \\
\hline $1-7$ & Head length & 40.8 & 13 & $33.5-38.9$ & $36.4 \pm 2.0$ & 47.0 & 30 & $32.4-39.5$ & $35.1 \pm 1.7$ \\
\hline $7-10$ & Head-dorsal length & 9.6 & 12 & $7.6-9.0$ & $8.2 \pm 0.4$ & 9.3 & 30 & $6.2-10.4$ & $7.8 \pm 0.8$ \\
\hline $8-9$ & Cleithral width & 37.6 & 13 & $30.6-36.1$ & $33.6 \pm 1.5$ & 45.2 & 30 & $31.7-37.0$ & $33.6 \pm 1.4$ \\
\hline $8^{\prime}-9^{\prime}$ & Cleithral width ventral & 37.0 & 12 & $31.7-34.7$ & $33.1 \pm 1.2$ & 44.8 & 29 & $29.9-36.3$ & $32.9 \pm 1.4$ \\
\hline $1-12$ & Head-pectoral length & 32.3 & 13 & $24.7-31.1$ & $27.7 \pm 1.7$ & 37.5 & 30 & $23.3-35.7$ & $27.3 \pm 2.3$ \\
\hline $12-13$ & Thorax length & 27.8 & 13 & $23.7-31.3$ & $26.9 \pm 2.0$ & 35.3 & 30 & $22.5-29.1$ & $25.5 \pm 1.6$ \\
\hline $12-29$ & Pectoral-spine length & 37.0 & 13 & $29.0-34.8$ & $32.3 \pm 1.6$ & 44.6 & 30 & 29.3-36.7 & $32.4 \pm 1.6$ \\
\hline $13-14$ & Abdominal length & 25.5 & 13 & $18.6-23.9$ & $22.1 \pm 1.5$ & 28.6 & 30 & $20.1-24.6$ & $22.4 \pm 1.0$ \\
\hline $13-30$ & Pelvic-spine length & 30.7 & 13 & $25.4-31.6$ & $28.6 \pm 1.5$ & 37.6 & 29 & $25.3-31.8$ & $28.2 \pm 1.5$ \\
\hline 13-13' & Pelvic girdle width & 24.5 & 13 & $19.2-22.9$ & $21.6 \pm 1.0$ & 28.8 & 30 & $19.1-23.2$ & $20.9 \pm 0.8$ \\
\hline $14-15$ & Postanal length & 31.6 & 13 & $29.6-35.6$ & $32.5 \pm 2.0$ & 52.2 & 30 & $31.8-40.3$ & $35.7 \pm 1.8$ \\
\hline 14-31 & Anal-fin spine length & 17.5 & 13 & $10.6-17.3$ & $14.9 \pm 1.9$ & 20.7 & 27 & $10.4-16.0$ & $14.8 \pm 1.2$ \\
\hline $10-12$ & Dorsal-pectoral depth & 35.1 & 13 & 29.8-32.9 & $30.9 \pm 1.1$ & 39.7 & 30 & 28.1-33.4 & $30.3 \pm 1.5$ \\
\hline $10-11$ & Dorsal-spine length & 35.2 & 9 & $27.5-34.0$ & $31.6 \pm 2.0$ & - & 18 & 27.4-35.7 & $32.0 \pm 2.4$ \\
\hline $10-13$ & Dorsal-pelvic depth & 29.2 & 12 & 22.4-31.9 & $27.1 \pm 2.5$ & 36.7 & 30 & $19.9-32.0$ & $24.7 \pm 2.4$ \\
\hline $10-16$ & Dorsal-fin base length & 31.4 & 12 & 23.2-29.4 & $25.8 \pm 1.5$ & 38.4 & 30 & $24.1-29.5$ & $26.6 \pm 1.2$ \\
\hline $16-17$ & Dorsal-adipose distance & 17.7 & 13 & $16.3-24.5$ & $18.4 \pm 2.1$ & 24.3 & 30 & $16.3-20.9$ & $18.5 \pm 1.4$ \\
\hline $17-18$ & Adipose-spine length & 9.1 & 13 & $5.9-8.7$ & $7.8 \pm 0.8$ & 10.7 & 30 & $6.8-9.6$ & $8.1 \pm 0.7$ \\
\hline $17-19$ & Adipose-upper caudal distance & 12.6 & 13 & $11.8-16.6$ & $14.0 \pm 1.4$ & 21.4 & 30 & $6.1-19.4$ & $15.7 \pm 2.2$ \\
\hline 15-19 & Caudal peduncle depth & 14.9 & 12 & $10.9-14.0$ & $12.1 \pm 0.9$ & 15.8 & 30 & $9.8-12.1$ & $11.1 \pm 0.5$ \\
\hline $20-32$ & $\begin{array}{l}\text { Caudal peduncle-middle caudal } \\
\text { ray }\end{array}$ & 21.6 & 7 & $17.7-20.3$ & $18.9 \pm 0.9$ & - & 25 & $14.0-20.7$ & $17.3 \pm 1.6$ \\
\hline $20-33$ & $\begin{array}{l}\text { Caudal peduncle-dorsal caudal } \\
\text { spine }\end{array}$ & - & 2 & $32.8-39.6$ & $36.2 \pm 4.8$ & - & 2 & $36.4-65.1$ & $50.7 \pm 20.3$ \\
\hline $15-17$ & Adipose-lower caudal depth & 22.5 & 12 & $21.1-23.8$ & $22.8 \pm 0.9$ & 32.9 & 30 & $22.3-25.9$ & $23.6 \pm 0.9$ \\
\hline $14-17$ & Adipose-anal depth & 24.0 & 12 & $14.6-23.2$ & $20.7 \pm 2.5$ & 28.5 & 30 & $17.2-23.1$ & $20.7 \pm 1.3$ \\
\hline $14-16$ & Dorsal-anal depth & 20.2 & 12 & $14.9-20.0$ & $17.9 \pm 1.4$ & 23.2 & 30 & $14.8-19.7$ & $17.4 \pm 1.1$ \\
\hline $13-16$ & Pelvic-dorsal depth & 30.2 & 12 & $22.7-28.3$ & $26.5 \pm 1.8$ & 31.1 & 30 & 20.6-29.7 & $24.9 \pm 2.0$ \\
\hline \multicolumn{10}{|c|}{ Percent of Head Length } \\
\hline $5-7$ & Head-eye length & 15.3 & 13 & $33.9-46.4$ & $37.6 \pm 3.2$ & 17.0 & 30 & $32.9-39.0$ & $36.1 \pm 1.6$ \\
\hline $4-5$ & Orbit diameter & 5.7 & 13 & $13.6-21.8$ & $15.7 \pm 2.1$ & 6.8 & 30 & $14.2-20.0$ & $16.1 \pm 1.3$ \\
\hline $1-4$ & Snout length & 26.1 & 13 & $52.6-67.1$ & $61.2 \pm 4.7$ & 30.2 & 30 & $59.5-68.8$ & $62.9 \pm 2.1$ \\
\hline $2-3$ & Internares width & 5.4 & 12 & $10.3-17.1$ & $12.7 \pm 1.8$ & 6.1 & 30 & $11.0-14.5$ & $12.6 \pm 1.1$ \\
\hline $5-6$ & Interorbital width & 21.0 & 13 & $42.3-57.1$ & $50.1 \pm 3.8$ & 24.1 & 30 & $44.7-56.0$ & $50.8 \pm 2.6$ \\
\hline $5^{\prime}-6^{\prime}$ & Dorsal interorbital width & 16.3 & 13 & $33.9-53.7$ & $40.0 \pm 4.9$ & 19.2 & 30 & $36.9-44.9$ & $39.5 \pm 1.6$ \\
\hline $7-12$ & Head depth & 28.6 & 13 & $65.0-75.7$ & $71.7 \pm 3.3$ & 34.4 & 30 & $45.7-82.7$ & $72.9 \pm 5.9$ \\
\hline $1-24$ & Mouth length & 18.2 & 13 & $44.1-54.2$ & $46.4 \pm 2.7$ & 21.3 & 30 & $34.8-50.4$ & $44.0 \pm 3.1$ \\
\hline $21-22$ & Mouth width & 17.4 & 12 & $41.6-50.3$ & $44.1 \pm 2.5$ & 19.5 & 30 & $36.0-48.9$ & $42.3 \pm 3.3$ \\
\hline $22-23$ & Barbel length & 5.7 & 12 & 10.4-17.6 & $13.9 \pm 2.3$ & 4.3 & 29 & $6.9-15.8$ & $11.6 \pm 2.2$ \\
\hline \multicolumn{9}{|c|}{ Meristics } & Mode \\
\hline & Teeth on dentary (left/right) & $6 / 6$ & 12 & $4-7 / 5-7$ & $6 / 6$ & $6 / 7$ & 29/19 & $6-8 / 7-8$ & $6 / 6$ \\
\hline & Teeth on premaxillary (left/right) & $6 / 5$ & 12 & $5-7 / 5-7$ & $5 / 5$ & 7 & $29 / 19$ & $4-7 / 5-7$ & $6 / 5$ \\
\hline & Scut. Dorsal-fin base & 7 & 12 & $6-7$ & 7 & 7 & 30 & $6-7$ & 7 \\
\hline & Scut. between Dorsal/Adipose & 7 & 12 & $6-7$ & 6 & 6 & 30 & $5-7$ & 6 \\
\hline & Scut. between Adipose/Caudal & 5 & 12 & $5-8$ & 7 & 8 & 30 & $6-9$ & 7 \\
\hline & Scut. Anal fin base & 2 & 12 & 2 & & 2 & 30 & $2-3$ & 2 \\
\hline & Scut. between Anal/Caudal & 12 & 12 & $11-13$ & 11 & 12 & 30 & $11-14$ & 12 \\
\hline & Lateral scutes & 24 & 12 & $24-25$ & 24 & 26 & 30 & $23-26$ & 25 \\
\hline
\end{tabular}

Color in alcohol. Base coloration on body, head and fins light brown or olivaceous in large specimens (> $85 \mathrm{~mm} \mathrm{SL})$ or dark brown if smaller (Fig. 4). Fins showing dark and light bands in all sizes. Small individuals $(<25 \mathrm{~mm} \mathrm{SL})$ with four clear light bands on trunk, nearly as wide as the dark interspaces; fine light lines on head, going from eyes to the margin; abdomen light without dark markings. Medium sized specimens (25-85 mm SL) with 5 to 9 light bands on trunk. Number of bands increasing with size. Anterior bands very thin, slightly thickening towards the caudal fin. Markings on head only visible in smaller individuals. Abdomen dark brown with irregular white worm lines. Large specimens without bands on trunk and light markings on abdomen or with only some faint traces of them. Coloration light brown or olivaceous with darker or lighter shadows.

Sexual dimorphism. No clear sexual dimorphism could be observed in the specimens examined. 


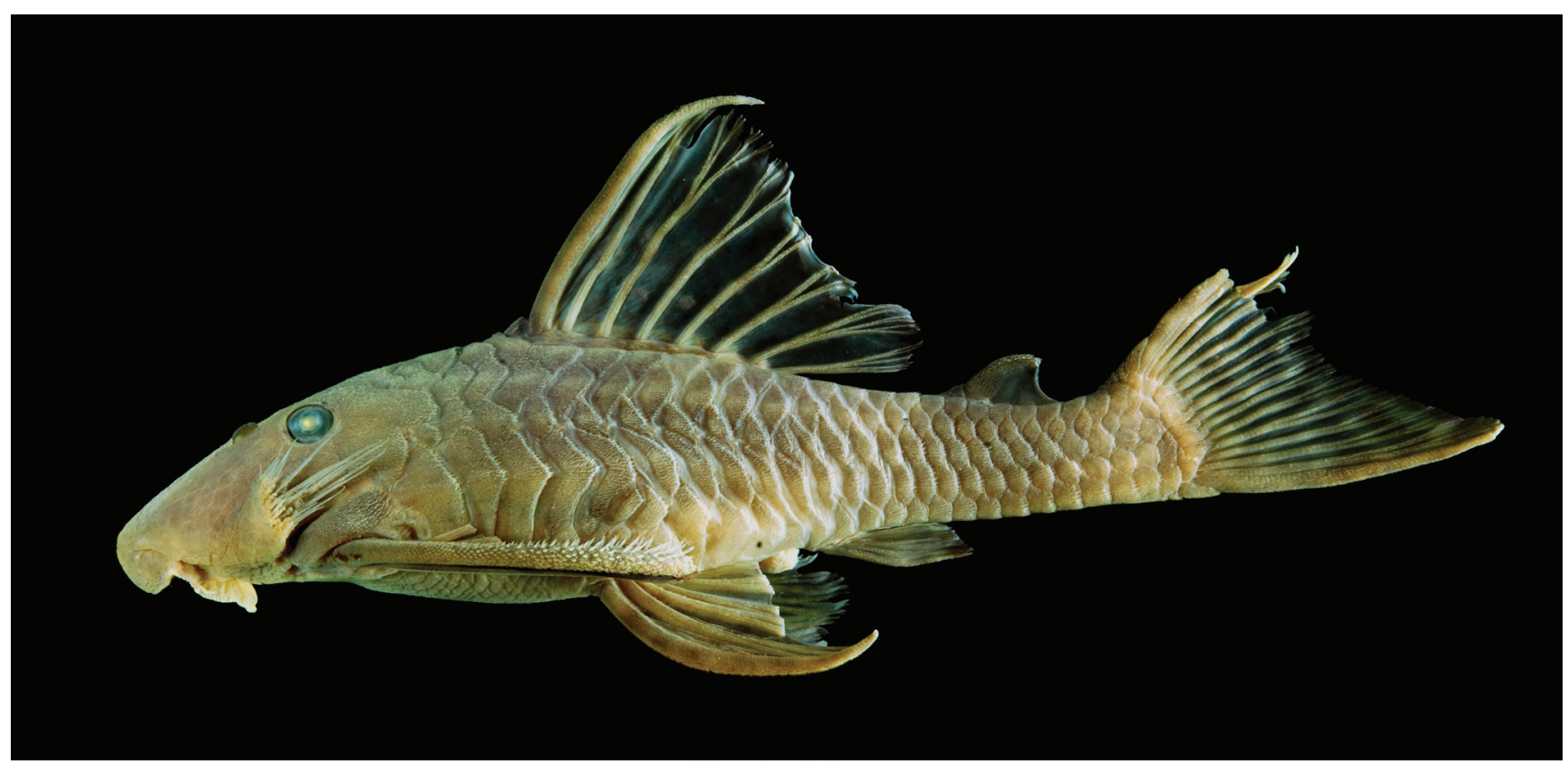

Fig. 5. Lateral view of an adult Panaqolus nocturnus (AUM 45528, $137.4 \mathrm{~mm} \mathrm{SL}$ ) to show the similarity between adult $P$. nocturnus and P. purusiensis. Photo by B. S. F. Barros.

Distribution and Habitat. The species is known from the upper Purus drainage (Fig. 7). Some of the specimens were caught at night with a cast net on stony bottom in strong current (MCP 45733). Others had been picked by hand from holes in rotten wood in low current (UFRO-I 17720).

\section{Discussion}

Panaqolus purusiensis was described some 80 years ago, but still very little is known about it. While searching museum databases for specimens for this project, individuals identified as P. purusiensis where found from localities in Peru, Brazil, Colombia and even French Guiana. All these specimens had been collected before the publication of the revision of the Panaque-dentex-group (Schaefer \& Stewart, 1993). The only other species of small Panaque (now Panaqolus) that was described before 1993 is $P$. dentex (Günther, 1868), although it had been published as Chaetostomus dentex. That might be the reason why $P$. purusiensis is the most commonly used name for specimens collected before the revision of Schaefer \& Stewart (1993), without regard to where they had been caught.

It is not clear why and when the material collected by Krukoff in 1934 was split and deposited in at least three different collections on two continents (AMNH, New York; USNM, Washington D.C.; MSNM, Milan). LaMonte apparently did not know about this additional material, but for the present study, all three specimens of Panaqolus collected by Krukoff could be examined. Unfortunately, these three have lost virtually all coloration. Specimens from more recent collections show that very small individuals have a color pattern very similar to other species from this genus. Medium sized specimens show a unique color pattern, but in large fish the bands on the trunk are fading, making them very difficult to be distinguished from P. nocturnus.

Unfortunately, none of the characters mentioned by LaMonte (1935) actually serves to identify the species. She wrote: "This species differs from others described in the number of scutes bordering the supraoccipital; in its depth; the fact that the temporal plates are not carinate; its dorsal count, the length of the interopercular spines; and the tooth count which is lower than that of the other species." More than likely she only referred to the large species of Panaque and did not know about Panaqolus dentex, the only species of that genus which had been described at that time. The number of scutes bordering the supraoccipital varies from two to three, a number also found in congeners (vs. apparently only one in Panaque). "Its depth" probably refers to the body depth,

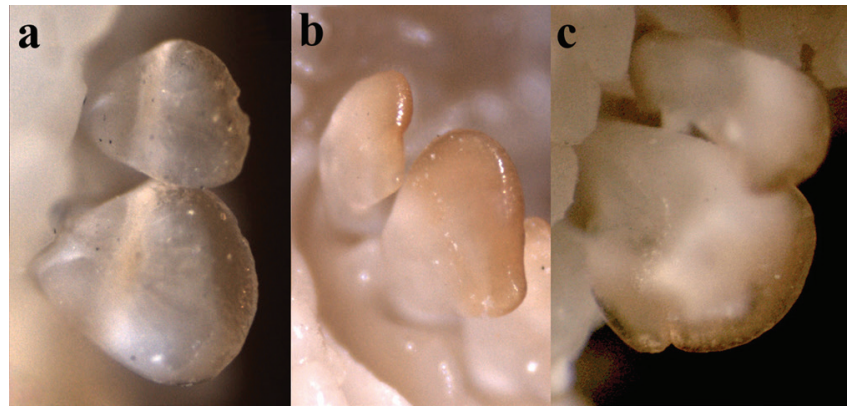

Fig. 6. Teeth of Panaqolus purusiensis: a) Teeth without lateral dent (UFRO-I 17720, premaxilla); b) teeth with rudiment of a lateral cusp in form of a small lateral dent (MUSM 39425, dentary); c) tooth with small lateral cusp (MCP 45733, dentary). 
albeit P. purusiensis do not differ from other Panaqolus on this point; Panaque subjectively have a higher body, but the measurements taken here do not support this statistically. The temporal plates of all Panaqolus are not carinate, but those of at least some Panaque species are. The dorsal fin of the holotype has eight rays, but all other examined specimens have seven, as usual in Ancistrini. Among 150 examined Panaqolus only one more individual was found to have eight dorsal rays (P. nocturnus; AUM 45558). The same findings were made for Pseudancistrus barbatus (one out of 174) and Parancistrus aurantiacus (one out of 15), showing that these variations are rare but normal. The cheek odontodes of $P$. purusiensis are not longer than in other congeners, but Panaque may have remarkably long odontodes (reaching past the second plate after pectoral-fin insertion). The tooth count in P. purusiensis is more or less the same as in other species of the genus, but less than the number in Panaque (3-8 per ramus vs. 4-24 [Lujan et al., 2010]).

Schaefer \& Stewart (1993) mention that P. purusiensis and $P$. nocturnus could be distinguished by a smaller orbit diameter, a deeper caudal peduncle, and less scutes in the lateral line. Unfortunately these findings could not be confirmed. The eyes of both species have nearly the same size $(13.6-21.8 \% \mathrm{HL}$ vs. $14.2-20.0 \% \mathrm{HL}$ ), the caudal peduncle usually is a little bit deeper, but with a large overlap (10.9-14.0\% SL [mean 12.1\%] vs. 9.8-12.1\% SL [mean 11.1\%]), and P. purusiensis has 24-25 [mode 24] plates in the lateral line versus 23-26 [mode 25] in $P$. nocturnus, showing again a tendency but no clear distinction. Despite these similarities, there is no doubt that $P$. purusiensis and $P$. nocturnus are distinct species as their distributions are clearly separated (rio Purus basin vs. rio Marañón basin; Fig. 7) and the trunk coloration of juvenile and subadult specimens is noticeably different (alternating light and dark bands $v s$. diffuse lighter markings on dark ground, but never showing bands).

The genus Panaqolus is not widely accepted, but previous results from molecular studies showed the genus to be clearly separated from Panaque (Cramer et al., 2011; Nathan Lujan, unpublished data, pers. comm.). Schaefer \& Stewart (1993) list some morphological characters to separate the two genera, but Armbruster (2004) found them to be closely related and treated them as synonyms. Given the morphological characters from Schaefer \& Stewart (1993) and first molecular results, the genus Panaqolus is being used here, following other recent publications (Eschmeyer, 2012; Ferraris, 2007; Fisch-Muller

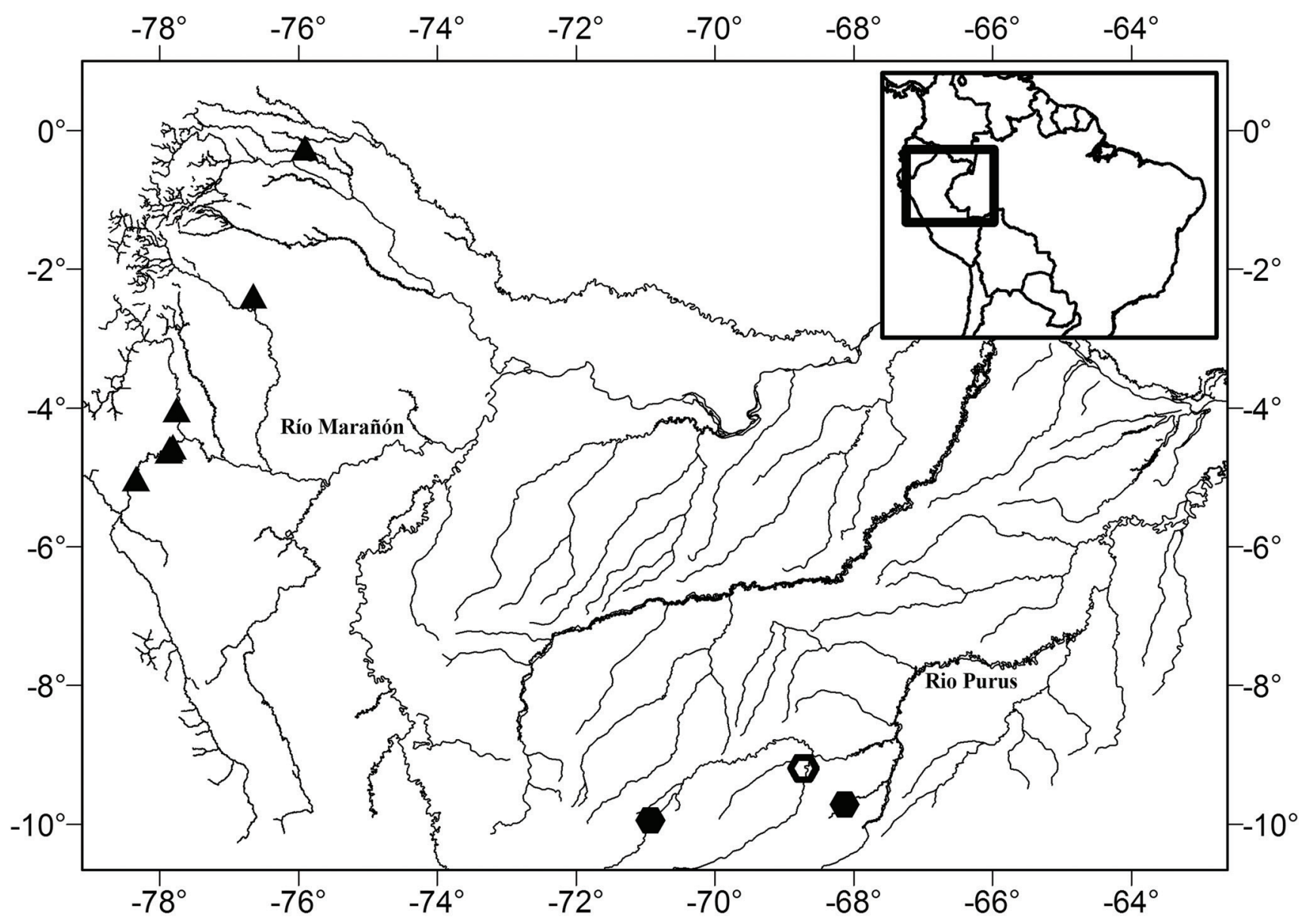

Fig. 7. Distributions of Panaqolus purusiensis (hexagon) and P. nocturnus (triangle). Open symbol: type locality. Symbols may represent more than one locality or lot. 
et al., 2012). A further molecular study to test the validity of this genus and its monophyly is in preparation.

\section{Key to the species of Panaqolus (modified from Chockley \& Armbruster, 2002)}

1 Head, body and fins without alternating dark and light bands

1 ' Head, body and/or fins (in P. nocturnus and adult $P$. purusiensis only on fins [at least anal and pelvic fins]) with alternating dark and light bands ........................................ 4

2 Dentaries in an angle of approximately $70^{\circ}$, forming a V (Fig. 1a). Normally dentaries meet in the middle; body and fins not covered with small light dots; maxillary barbels elongate, approximately $20-40 \%$ of disk width .......... 3

2' Dentaries in a very acute angle or nearly parallel, normally not meeting in the middle, forming $\mathrm{a} \backslash /$ (Fig. 1b); body and fins covered with small white or yellowish dots; maxillary barbels short, approximately $15 \%$ disk width (upper río Amazonas, río Ucayali, río Napo, and río Marañón drainages) P. albomaculatus

3 Body uniformly grayish black; teeth quadrate with strong lateral cusp (upper Maroni River basin, French Guiana) ... P. koko

3' Body dark with three lighter saddles between dorsal and caudal fins; teeth rounded without or with tiny lateral cusps (upper río Amazonas, río Ucayali, río Napo, and río Marañón drainages) P. dentex

4 Dark body with diffuse lighter markings; never showing bands or stripes on body or head (upper río Amazonas, río Ucayali, río Napo, and río Marañón drainages)

P. nocturnus

4' Body with alternating light and dark bands, at least in individuals $<90 \mathrm{~mm} \mathrm{SL}$ ... 5

5 Bars angled in an anterodorsal to posteroventral direction on trunk (upper río Amazonas, río Ucayali, río Napo and río Marañón drainages) P. gnomus

5' Bars angled in a posterodorsal to anteroventral direction on trunk

6 Dark bars on trunk and bands on dorsal fin as wide as or thinner than light interspaces; trunk with 6-12 (mode = 8) dark bars; adipose with 1-2 (usually 2) dark bands (río Nanay and río Itaya drainages)

P. changae

6' Dark bars on trunk and bands on dorsal fin much wider than light interspaces (in specimens larger than $25 \mathrm{~mm} \mathrm{SL}$; specimens larger than $85 \mathrm{~mm}$ SL may not show clear bands on the trunk); trunk with 3-9 dark bars . ... 7

7 Small adult size (max. $87 \mathrm{~mm}$ SL, usually smaller); trunk with 3-7 $($ mode $=4)$ dark bars; dorsal-pelvic depth 19-23\% (mean $=21 \%$ ) of SL (río Orinoco drainage)

P. maccus
7' Large adult size (max. $130.4 \mathrm{~mm} \mathrm{SL}$ ); trunk with 5-9 (mode $=7$ ) dark bars in specimens larger than $25 \mathrm{~mm} \mathrm{SL} \mathrm{(smaller}$ specimens with 4 bars; specimens larger than $85 \mathrm{~mm} \mathrm{SL}$ may not show clear bands on the trunk); dorsal-pelvic depth $22-32 \%$ (mean $27 \%$ ) of SL (rio Purus drainage)

P. purusiensis

Material examined. Panaqolus albomaculatus: Ecuador: USNM 167909, holotype, $91.1 \mathrm{~mm} \mathrm{SL}$, río Pucuno, tributary of Suno (altitude 350-400 m). USNM 167910, paratype, $81.7 \mathrm{~mm} \mathrm{SL}$, río Cotapino, tributary of río Pucuno. USNM 167908, paratypes, 4, 48.5-78.5 mm SL, Pastaza, río Bobonaza, Pastaza drainage. Peru: Amazonas: AUM 45502, 5, 39.6-103.7 mm SL, río Marañón, log riffle, 1.57 km ENE of Juan Valesco (Sta Maria de Nieva). AUM 45507, 5, 79.1-114.8 mm SL, río Marañón, log riffle, 1.57 km ENE of Juan Valesco (Sta Maria de Nieva). LACM 36357-33, $72.3 \mathrm{~mm}$ SL, río Cenepa, vicinity of Huampami. LACM 42001-9, 2, 91.4113.3 mm SL, $100 \mathrm{~m}$ downstream from Caterpiza. LACM 41740-18, 99.8 mm SL, río Marañón at confluence with río Nieva at Sta. Maria de Nieva. LACM 36330-5, $120.2 \mathrm{~mm} \mathrm{SL}$, Caterpiza, quebrada. LACM 42005-10, $94.6 \mathrm{~mm} \mathrm{SL}, 1 \mathrm{~km}$ upstream from Caterpiza. LACM 36313-3, 2, 84.9-96.1 mm SL, Peru, Amazonas, río La Poza. LACM 42115-6, 54.8 mm SL, Caterpiza. UFRO-I 17825, $77.5 \mathrm{~mm}$ SL, aquarium specimen. Panaqolus changae: Peru: Loreto: MUSM 17107, holotype, $58.8 \mathrm{~mm} \mathrm{SL}$, río Itaya, $11 \mathrm{~km} \mathrm{SSW}$ center of Iquitos at bearing $39^{\circ}$. SIU 29928, paratype, $45.2 \mathrm{~mm} \mathrm{SL}$, río Itaya, 11 $\mathrm{km}$ SSW center of Iquitos at bearing $39^{\circ}$. INHS 42419, paratypes, 2, $38.5-83.0 \mathrm{~mm} \mathrm{SL}$, río Itaya, $11 \mathrm{~km} \mathrm{SSW}$ center of Iquitos at bearing $39^{\circ}$. AUM 28908, 5, 53.0-84.5 mm SL, río Momon, ca. 8 hours by boat from Iquitos. Panaqolus dentex: Peru: Loreto: BMNH1867.6.13.37, holotype, $58.8 \mathrm{~mm}$ SL, rio Xeberos, Huallaga drainage. Amazonas: FMNH 96952, 73.8 mm SL, Peru, Amazonas, Caterpiza. LACM 39892-1, 3, 46.9-67.7 $\mathrm{mm}$ SL, Shaime, village on río Yutupis, from small quebrada. LACM 41993-6, 2, 66.9-68.3 mm SL, $3 \mathrm{~km}$ upstream from Caterpiza. LACM 41995-3, $71.1 \mathrm{~mm}$ SL, $3 \mathrm{~km}$ upstream from Caterpiza-Kusuim. LACM 36329-6, $41.4 \mathrm{~mm}$ SL, Caterpiza, quebrada. LACM 41946-1, $38.3 \mathrm{~mm}$ SL, $200 \mathrm{~m}$ upstream from Caterpiza. LACM 39952-1, 4, 43.6-72.9 mm SL, Small Quebrada in Galilea, tributary to río Santiago. AMNH 218002, 76.7 mm SL, río Santiago. Ecuador: Napo: FMNH 97595, 2, 67.6-73.5 mm SL, Quebrada Apoalla, tributary to lower río Shushufindi, Napo drainage. FMNH 97596, 2, 74.1-78.4 mm SL, lower río Bobonaza at Chicherata, about $25 \mathrm{~km}$ upstream from mouth of río Pastaza. FMNH 97593, $41.4 \mathrm{~mm}$ SL, Estero Samonayacu, about $3.5 \mathrm{~km}$ SW of the bridge over río Napo along road from Coca to río Tiputini. Panaqolus gnomus: Ecuador: Pastaza: FMNH 70860, holotype, $56.5 \mathrm{~mm} \mathrm{SL}$, Cusuimi, on río Cusuimi, about $150 \mathrm{~km}$ SE of Puyo. FMNH 97598, paratypes, 2, 56.0$56.1 \mathrm{~mm}$ SL, río Bobonaza at Sarayacu, Pastaza drainage. FMNH 97597, paratypes, 3, 53.0-55.7 mm SL, Cusuimi, on río Cusuimi, about $150 \mathrm{~km}$ SE of Puyo. Orellana: USNM 163912, paratype, $60.9 \mathrm{~mm}$ SL, Orellana, río Suno, upper, Napo drainage. Peru: Amazonas: FMNH 96950, paratype, $69.2 \mathrm{~mm} \mathrm{SL}$, río Cenepa, vicinity of Huampami, elevation 700m. LACM 42005-11, paratype, $62.0 \mathrm{~mm} \mathrm{SL,} 1 \mathrm{~km}$ upstream from Caterpiza. LACM 42115-7, paratypes, 2, 59.9-67.7 mm SL, Caterpiza. LACM 41992-6, paratypes, 2, 59.3-63.6 mm SL, $500 \mathrm{~m}$ upstream from Caterpiza. LACM 36330-4, paratypes, 2, 59.8-63.2 mm SL, Caterpiza, quebrada. AUM 45505, 5, 51.0-64.3 mm SL, río Marañón, log riffle, 1.57 km ENE of Juan Valesco (Sta Maria de Nieva). AUM 45501, 10, 47.068.3 mm SL, same data as AUM 45505. Panaqolus koko: SMF 9702, 84.7 mm SL, French Guyana: Saint Laurent du Maroni: Maroni River, Saut Ga-kaba to Apatou. Panaqolus maccus: Venezuela: MCBUCV-V 24010, holotype, $66.0 \mathrm{~mm} \mathrm{SL}$, Portuguesa, río Las Marinas, upstream from 
bridge on Route 5 east of Cuanare, tributary of río Portugesa. FMNH 97603, paratypes, 3, 29.0-49.8 mm SL, same data as holotype. FMNH 105998, 3, 31.8-52.2 mm SL, Barinas, río Anaro, ca. 10 minutes from mouth in río Suripa, río Apuré drainage. USNM 265675, $31.6 \mathrm{~mm} \mathrm{SL}$, Bolivar, río Orinoco, Cove, Tslote de Fajardo, 182 nautic miles upstream from Sea Buoy. Panaqolus nocturnus: Peru: Amazonas: LACM 4172951, holotype, $138.9 \mathrm{~mm}$ SL, río Santiago at La Poza. FMNH 96955, paratypes, $137.8 \mathrm{~mm} \mathrm{SL}$, río Santiago at La Poza, outside mouth of quebrada by airport. LACM 41729-35, paratypes, 4, 71.3-123.4 mm SL, río Santiago at La Poza. LACM 41723-5, paratypes, 4, 111.1-123.5 mm SL, río Santiago at La Poza. AUM 45558, 6, 68.4-116.6 mm SL, río Marañón, $6.3 \mathrm{~km}$ NE of Juan Velasco (Sta Maria de Nieva). AUM 45500, 2, 130.5143.9 mm SL, río Marañón, log riffle, 1.57 km ENE of Juan Velasco (Sta Maria de Nieva). AUM 45508, 3, 69.8-101.5 mm SL, río Marañón, 12 km N Imacita. Ecuador: Pastaza: FMNH 97600, paratypes, 2, 66.7-96.9 $\mathrm{mm}$ SL, lower río Bobonaza at Chicherota, ca. $25 \mathrm{~km}$ upstream from mouth with río Pastaza. Napo: FMNH 97599, paratypes, $121.5 \mathrm{~mm} \mathrm{SL}$, río Aguarico near Destacamento militar Cuyabeno and confluence of río Cuyabeno - río Aguarico, Napo drainage. USNM 167907, paratypes, 2, 103.5-109.0 mm SL, río Bobonaza, Napo drainage. USNM 177209, paratype, $92.2 \mathrm{~mm} \mathrm{SL}$, río Bobonaza at Chicherota, about $25 \mathrm{~km}$ upstream from mouth in río Pastaza. Panaqolus purusiensis: Brazil: Acre: AMNH 12600, holotype, $106.7 \mathrm{~mm}$ SL, vicinity of the mouth of rio Macauã (or Macauhan), a tributary of rio Iaco (or Yaco), which, in turn, is a tributary of rio Purus $\left(09^{\circ} 11^{\prime} S 68^{\circ} 43^{\prime} \mathrm{W}\right), 1934$, B. A. Krukoff. USNM 94665, 1, $110.6 \mathrm{~mm}$ SL, same data as holotype. MSNM Pi43, 1, $126.4 \mathrm{~mm}$ SL, same data as holotype. UFRO-I 17720, 11, 15.5-83.1 mm $\mathrm{SL}$, rio Macauã near mouth with rio Iaco ( $\left.9^{\circ} 11^{\prime} 27^{\prime \prime S} 68^{\circ} 43^{\prime} 12^{\prime \prime} \mathrm{W}\right), 16$ Aug 2011, C. A. Cramer \& J. A. L. Filho. UFRO-I 17723, 1, 15.7 mm SL, rio Macauã near mouth with rio Iaco (09¹1'24”S 68 43'08”W), 16 Aug 2011, C. A. Cramer \& J. A. L. Filho. MCP 35621, 2, 59.7-78.1 mm SL, rio Riozinho do Andirá at BR-364 between Rio Branco and Sena Madureira (0943’21'S 6807’45”W), 22 Jul 2004, R. Reis et al. Peru: Ucayali: MCP 45733, 2, 107.6-114.0 mm SL, río Curanja near confluence with río Purús (0957’06”S 7055’33”W), 25 Jul 2010, R. Reis et al. MUSM 39425 , $1,130.4 \mathrm{~mm}$ SL, río Curanja at mouth with río Purus (0957'10.9”S 7055'56.6”W), 25 Jul 2010, J. Albert et al. Panaque armbrusteri: Brazil: Pará: INPA 37460, 6, 70.9-74.7 mm SL, Xingu drainage. ZMA 120.179, 1, 345 mm SL, rio Itacaiunas. Panaque sp.: Brazil: Goiás: MNRJ 13299, 7, 103.1-122.0 mm SL, rio Tocantins near Minaçu. MNRJ 13297, 1, 209.0 mm SL, rio Tocantins near Minaçu. Parancistrus aurantiacus: Brazil: without locality: ZMA 119.815, 4, 50-64 mm SL. ZMA 119.388, 2, 7494 mm SL. ZMA 120.463, 2, 99-125 mm SL. Pseudancistrus barbatus: Suriname: without locality: ZMA 106.331, 174, 38-203 mm SL.

\section{Acknowledgments}

I am grateful to João Alves de Lima Filho (UNIR) and Lisandro Juno (UFAC) for their support during the fieldtrip to the type locality. Thanks are due to James Maclaine (BMNH), Giorgio Bardelli (MSNM), Jonathan Armbruster (AUM), Richard Vari (USNM), Leo Smith and Kevin Swagel (FMNH), and Rick Feeney (LACM) for receiving me at their museum collections. Andreas Tanke (Neustadt am Rübenberge, Germany) contributed with valuable discussions about the genus Panaqolus. Diogo Hungria compiled the distribution map and helped taking the pictures of the teeth. Kevin Swagel and Julian Dignall improved considerably the English of my manuscript. Andrea de Carvalho Paixão and two anonymous reviewers revised the manuscript and helped to improve it. Financial support: DCR fellowship from CNPq and SEPLAN-RO (process 350674/2010-8). I am especially grateful to my wife Tassiana D. B. P. Cramer who supported all my fieldtrips and travel to visit museum collections.

\section{Literature Cited}

Armbruster, J. W. 2004. Phylogenetic relationships of the suckermouth armoured catfishes (Loricariidae) with emphasis on the Hypostominae and the Ancistrinae. Zoological Journal of the Linnean Society, 141: 1-80.

Armbruster, J. W. 2008. The genus Peckoltia with the description of two new species and a reanalysis of the phylogeny of the genera of the Hypostominae (Siluriformes: Loricariidae). Zootaxa: 3-76.

Braitmayer, S. 2010. L-Nummern aus Kolumbien. Die Aquarien und Terrarien Zeitschrift (DATZ), 63: 32.

Chockley, B. R. \& J. W. Armbruster. 2002. Panaque changae, a new species of catfish (Siluriformes: Loricariidae) from eastern Peru. Ichthyological Exploration of Freshwaters, 13: 81-90.

Conci, C. \& M. Michelangeli. 1974. Catalogo dei tipi del Museo Civico de Storia Naturale di Milano I. I Tipi dei pesci, con note storiche sulla collezione ittiologica Atti della Societa Italiana di Scienze Naturali e del Museo Civico di Storia Naturale di Milano, 115: 213-237.

Cramer, C. A., S. L. Bonatto \& R. E. Reis. 2011. Molecular phylogeny of the Neoplecostominae and Hypoptopomatinae (Siluriformes: Loricariidae) using multiple genes. Molecular Phylogenetics and Evolution, 59: 43-52.

Eschmeyer, W. N. (Ed.). 2012. Catalog of Fishes. California Academy of Sciences. Available from: http://research.calacademy.org/ research/ichthyology/catalog/fishcatmain.asp (19 March 2012).

Ferraris, C. J. 2007. Checklist of catfishes, recent and fossil (Osteichthyes : Siluriformes), and catalogue of siluriform primary types. Zootaxa, 1418: 1-548.

Fisch-Muller, S. 2003. Subfamily Ancistrinae. Pp. 373-401. In: Reis, R. E., S. O. Kullander \& J. Carl J. Ferraris (Eds.). Check List of the Freshwater Fishes of South and Central America. EDIPUCRS, Porto Alegre.

Fisch-Muller, S., J. I. Montoya-Burgos, P.-Y. Le Bail \& R. Covain. 2012. Diversity of the Ancistrini (Siluriformes: Loricariidae) from the Guianas: the Panaque group, a molecular appraisal with descriptions of new species. Cybium, 36: 163-193.

Isbrücker, I. J. H., I. Seidel, J. P. Michels, E. Schraml \& A. Werner. 2001. Diagnose vierzehn neuer Gattungen der Familie Loricariidae Rafinesque, 1815 (Teleostei, Ostariophysi). Die Aquarien und Terrarien Zeitschrift (DATZ): 17-24.

LaMonte, F. R. 1935. Fishes from Rio Jurua and Rio Purus, Brazilian Amazonas. American Museum Novitates, 784: 1-8.

Lujan, N. K., M. Hidalgo \& D. J. Stewart. 2010. Revision of Panaque (Panaque), with descriptions of Three New Species from the Amazon Basin (Siluriformes, Loricariidae). Copeia, 2010: 676-704.

Miller, M. 2002. Loricariiden aus dem Takutu River. Die Aquarien und Terrarien Zeitschrift (DATZ), 55: 56.

Schaefer, S. A. \& D. J. Stewart. 1993. Systematics of the Panaque dentex species group (Siluriformes: Loricariidae), wood-eating armored catfishes from tropical South America. Ichthyological Exploration of Freshwaters, 4: 309-342.

Submitted May 2, 2013 Accepted October 14, 2013 by Francisco Langeani Published March 31, 2014 